\title{
Research on the Venture Legal Risk Analysis and Prevention for College Students
}

\author{
Shijie Guo ${ }^{1, a}$ \\ ${ }^{1}$ Fuzhou University, Fuzhou, Fujian, China, 350116 \\ aemail,
}

Keywords: Venture, Legal Risk Analysis, Prevention, College Students

\begin{abstract}
With the increasingly severe employment situation of college students, college students in order to effectively solve the employment problem, the Chinese government actively encourages business students, entrepreneurs hope to boost employment of college students. As competition between industries increasingly fierce, so also rising legal risk students in the process of entrepreneurship in the face. Therefore, the study of law students in the entrepreneurial process of risk present in the analysis and propose appropriate preventive measures, aimed at promoting a better university student entrepreneurship.
\end{abstract}

\section{Introduction}

With enrollment in Chinese universities in recent years, the number of university graduates is increasing and more and more college students' employment situation is grim. In order to effectively solve the employment problem of college students, the government actively implements the "Students start to lead the program, and hope to improve the entrepreneurial enthusiasm of college students, college students venture to boost employment. With the rapid development of China's economy has become even more intense competition in all walks of life, which Students makes entrepreneurs in the creation and operation of enterprises in the process environment facing more and more complex, the risk faced by also increasing, especially legal risk students into the community just because of a serious lack of legal awareness and social experience in the course of business-related legal disputes often caught them, so that enterprises suffer serious losses. Currently legal risk contracts, taxation, intellectual property and labor and employment and other students in the course of business faced rising, therefore, Students legal risk in the entrepreneurial process of the existence of research and analysis becomes increasingly important.

\section{The Concept of Venture Legal Risk of College Students}

The so-called legal risk refers to the risk in a particular environment, at a particular period of time, the possibility of some kind of loss, the constituent elements of the risk of major risk factors. The risk of accidents and the risk of losses, that is, the risk is at a given time period, the distance created between people achieve goals and results actually appear in expectations, the so-called legal risk refers to the process of law implementation, the possibility of some adverse legal consequences due to the specific legal act does not regulate the behavior of people making and behavior caused people to achieve the desired goals contrary, legal risk refers to business students in the College Students' practice in the process of entrepreneurship legal risk, is incompatible with the outside by a change in the legal environment of college students or college students start their own legal rights in practice. It does not meet legal obligations prescribed by law, the possibility of some adverse legal consequences arising in the process of college students venture.

\section{The Venture Legal Risk of College Students}

The Legal Risks Exist in the Process of the Establishment of Entrepreneurial Organization. According to relevant provisions of the Civil and Commercial Law regulations, at different organizational forms of business conditions, investors assume the responsibilities and obligations 
are different, the resulting risk is different. For individual businesses, individual investors owned enterprises, the need for unlimited liability for the debts arising. For the partnership, the two main forms: in the form of ordinary partnership, limited partnership form. When the ordinary form of partnership, the need to jointly and severally liable for the debts generated; when using a limited form of partnership, when general partners need to jointly and severally liable for the debts generated by its limited partners bear limited amount of investment prevail responsibility. For limited liability companies, all companies need to operate the property subject to a limited liability company is set up to assume, as investors need to prevail with its investment quota limited commitment.

Individual industrial and commercial households, individual-owned enterprises, partnership firms, investors and organizations in the form of a limited liability company is different, the establishment of appropriate procedures also vary, legal documentation requirements also vary. For tax policy, individual industrial and commercial households, individual-owned enterprises, as long as the partnership pay the corresponding personal income tax; and limited liability companies need to implement double taxation system. For this reason, business students, we must fully understand the organization of risk, organization and other forms of flexibility, according to their own perception and judgment to choose the appropriate form of organization to ensure business rationality, legality and feasibility. Venture larger the risk to bear the more, therefore, the best choice for a limited liability company in the form of entrepreneurship. But no matter what form selection, should follow the appropriate procedure to perform and carry out the relevant procedures to ensure procedures on the basis of documents complete before they can open for business.

The Legal Risks Exist in the Process of Operating the Venture Organization. With the rapid development of market economy, the contract has become a major nexus of market players and market players of all economic activities are inseparable from the contract. For any enterprise, in daily contact with a large number of activities will contract, signed with the time to perform the contract, in addition to economic business risk outside the enterprise also face penalties for illegal risk and credit default risk. Students entrepreneurs entering the community, the lack of social combat experience, and when other market players to carry out economic activities are often eager to win orders, not give a detailed review of the text of the contract, resulting in the trap of falling into each other, resulting in significant losses.

Also known as intellectual property rights intellectual achievements, refers to the rights of its own people according to the results of intellectual activity enjoyed by law, there are copyright, patent, trademark and it is a form of intangible assets. For patent, trademark acquisition, through application, examination, after approval before it can enjoy, and as long as the copyright is to meet the requirements can benefit. Once a subject acquired copyright, patent, trademark, etc., you can enjoy the exclusive right, and the right to exclude the use of other subjects, but in the exclusive right would also have the appropriate time limit. In practice, college students, entrepreneurs due to ignorance about the knowledge of intellectual property law or cannot lead to violations of the rights of others to maintain their own intellectual property rights cases abound. Therefore, students start the process, we must learn legal knowledge and understanding of intellectual property rights, at the same time does not infringe the rights of others, will protect their legal rights, intellectual property rights to avoid being invaded.

China's "Labor Law", "Labor Contract Law" clearly provides the employer the rights, obligations and legal responsibilities in the employment process. Students, entrepreneurs need to be familiar with the contents of these laws and regulations, so that it can at the same time does not infringe the rights of others, to protect their rights and interests will not be violated. In practice, however, college students venture enterprises are small-scale, need to recruit a lot of staff. Students start by understanding the situation, many companies sponsor generally less than 10 people, full-time staff actually recruited only 2-3 people, more recruitment of part-time staff and sponsors work together. For part-time workers, the companies do not sign labor contracts with them, so long as the agreement can reward; but will be restricted promoter agreement between the sponsor, dividends Under the agreement, the contents will not be involved in labor law Therefore, as long as the 
business and full-time staff to sign labor contracts, and the legal protection of the contractual relationship by Required by law, companies must be in strict accordance with working hours, rest and vacation, social security, wages and benefits companies such as implementation of the system.

The Legal Risks Exist in the Termination of Entrepreneurial Organizations. Students in the entrepreneurial process, the loss of civil subject is the main measure of entrepreneurial organization terminated. Students start the organization in the termination process, the two main risks: First, when college students has been terminated entrepreneurial activity, because there is no cancellation for the relevant procedures, resulting in criminals the opportunity to act, caused some damage. After the termination of entrepreneurial organization, because of different organizational forms, ultimately borne by the original debt also vary, if the organization is in the form of individual industrial and commercial households, individual-owned enterprises, partnership firms, need to jointly and severally liable for the debts generated; if organizational forms is a limited liability company, limited liability needs to prevail company property.

\section{The Causes of College Students Venture Legal Risk and Prevention Methods}

The Level of Entrepreneurs. Most of our students start was unsuccessful, mainly because of their lack of legal awareness of risk. Partly because the college students just out of school, lack of business knowledge and experience in corporate management, a lot of things did not follow the process of China's relevant laws and regulations, but in accordance with the wishes of the individual, extremely weak legal awareness, lack of legal risk prevention; on the other hand, China has a number of university students in the course of business, not subjected to the temptation of economic interests, although aware of the relevant actions will violate certain laws and regulations, but still take chances, bent, make some illegal things. Therefore, the students before the start should consciously study the relevant legal knowledge and experience things in daily life to think more from a legal point of view, to develop their own awareness of the law and legal thinking, improve their legal knowledge. In the process of the creation and management of enterprises, the introduction of the country to strictly observe relevant laws and regulations, standardize enterprise operational processes and institutional arrangements to prevent produce legal risks. Students' prior business, can choose their own first-related business projects successful companies to learn and practice, to understand their mode of operation and the company's rules and regulations related to the production, learning its management philosophy, summed up in its operation process is worth learning and irrational aspects to do better can actively introduce, irrational aspects can be improved in the course of their own use, effectively prevent the occurrence of legal risks. The company started in the choice of the top venture partner, to select entrepreneurial-minded partners, and to be clear that a partner during the partnership of the rights and obligations related to the breach of contract and corporate profit distribution, to prevent some of the entrepreneurial process related legal disputes.

The Level of Entrepreneurship Education. With respect to the Western countries, China's entrepreneurship education is still only in its infancy, many mechanisms are not yet perfect. Students' prior business, basically living in the campus, thus obtaining its relevant legal knowledge mainly from the upper classes, but at present most of our colleges and universities in the illegal school students legal education, usually only individual courses individual chapters cover the legal knowledge, such as the ideological and moral cultivation and legal basis. This is not conducive to the Students' Legal Consciousness. In order to better train legal consciousness of college students, first of all, schools should offer more courses related to law, in particular with entrepreneurship associated. Also, actively invite famous entrepreneurs, law professors and legal scholars related to lectures and universities, on the one hand to share their success and experience, on the other hand to explain the entrepreneurial process Students according to their own work experience legal risks may exist. Second, China's major colleges and universities to organize relevant teacher something about the entrepreneurial process of law books, and to open the relevant courses provide an opportunity to systematically study the relevant legal knowledge for prospective business school students of those illegal. Finally, in order to enable students to learn the theoretical knowledge and practical usually 
combine, in addition to the national level organized by the entrepreneurship competition, the College also actively organizes more games, so that students can simulate business processes. Meanwhile, the school also invited a number of entrepreneurs and relevant experts and scholars as guest reviews contest for students in the simulation of the entrepreneurial process reviews the problems and provide more professional and update messages, so that students a better understanding of the entrepreneurial process of legal risk.

The Government Level. At present, although our government departments at all levels have introduced a number of policies and regulations related to business students, but most of the policies and regulations with regard to fiscal and financial support and public service policies and regulations, business students about the current laws and policies and regulations above also blank Therefore, in order to more effectively fill the gaps, usually to the government on a regular basis to educate college students entrepreneurs of interrelated legal risks. In addition, relevant government departments will further deepen the reform of the enterprise system, to a reasonable successful experience of Western countries, and establish a sound system of entrepreneurship education curriculum guidance and entrepreneurship education system, while some college students venture to further enhance relevant local laws and regulations legal effect, guarantee the implementation and operation of related systems.

\section{Conclusion}

With increasingly fierce competition between industries, there are more and more legal risks for students in the venture process. In this study, we analyzed the legal risks for students in the early days, business operations and enterprise termination phase stage and proposed measures to avoid legal risks of college students in the entrepreneurial process from the level of entrepreneurship, education level and government level.

\section{References}

[1] Jia Xinzhang, Li Jingyuan. College Counselors, Vol. 6 (2012) No 53, p.25-26

[2] Peng Sue, Wang Yunhui, Wang Qunyong. System and Society, Vol. 12 (2015) No 27, p.74-76

[3] Hou XuSi. Innovation and Entrepreneurship Education, Vol. 30 (2014) No 19, p.144-145

[4] Wang Kuailiang. Career Guidance, Vol. 29 (2010) No 27, p.21-23

[5] Zhang Gongxu, Sun Jing. System and Society, Vol. 4 (2011) No 27, p. 281-289

（7-8 月）福建省晋江市青阳迎宾路银星花园 C601 郭仕捷 15959585859

(9月后) 福建省福州市闽侯县福州大学法学院 107 郭仕捷 15959585859 